\title{
ANALYSES OF USING DETERMINATION KEY ON VERTEBRATE ZOOLOGY COURSE TO IMPROVE CLASSIFICATION ABILITY AND CONCEPT ATAINMENT OF BIOLOGY EDUCATION STUDENTS
}

\author{
${ }^{1}$ Fransisca Sudargo, ${ }^{2}$ Hernawati \\ ${ }^{1,2}$ Biology Department, Faculty of Science and Mathematics Education \\ Indonesia University of Education \\ Jl. Dr. Setiabudhi No.229. Bandung 40154
}

\begin{abstract}
The aim of this study was to analyze the use of determination key on vertebrate zoology to improve classification ability and concept attainment of biology education students. Mixed method was used on this study that consist of both qualitative and quantitative analyses. Descriptive methods are used for qualitative analyses and the correlation methods for the quantitative analyses. Mixed method strategy by using triangulation concurrent because both qualitative and quantitative data were collected in the same time, and then compared to identify the convergence the differences or the combination of the data. The data analyses showed that by using the vertebrate zoology's determination key, could increase the students' classification ability and concept attainment of the students in Biology education department. The students' classification ability on reasoning the facts and the base of zoology vertebrate matter were increase. The highest score is for the ability of concept attainment (74.2\%). There were also the highest score on cognitive indicator of concept comprehension. The highest score were showed on concept applying (C3) that was 35.4 point. The high correlation between 'classification ability' and 'concept attainment' showed that there was positive impact on the use of the use of determination key toward concept attainment.
\end{abstract}

Keywords Determination key, Concept attainment, Classification ability, Vertebrate Zoology Course.

\begin{abstract}
Abstrak
Tujuan kajian ini adalah untuk menganalisis penggunaan kunci penentuan pada vertebrata zoologi untuk meningkatkan keupayaan klasifikasi dan konsep pencapaian pelajar pendidikan biologi. Kaedah penyelidikan campuran dalam kajian ini yang terdiri daripada analisis kuantitatif dan kualitatif. Kaedah deskriptif digunakan untuk analisis kualitatif dan kaedah korelasi bagi analisis kuantitatif. kaedah campuran strategi dengan menggunakan triangulasi serentak kerana data kualitatif dan kuantitatif yang dikumpul dalam masa yang sama, dan kemudian bandingkan untuk mengenalpasti penumpuan perbezaan atau gabungan data. Analisis data menunjukkan bahawa dengan menggunakan kekunci penentuan zoologi vertebrata ini, boleh meningkatkan keupayaan klasifikasi pelajar dan konsep pencapaian pelajar di Jabatan Pelajaran Biologi. Keupayaan pengkelasan pelajar pada takulan fakta-fakta dan perkara asas vertebrata Zoologi telah
\end{abstract}


meningkat. Markah tertinggi adalah kebolehan pencapaian konsep (74.2\%). Terdapat juga skor tertinggi pada penunjuk kognitif konsep kefahaman. Skor tertinggi telah menunjukkan konsep yang memohon (C3) itu adalah titik 35.4. Hubung-kait yang tinggi antara 'klasifikasi keupayaan' dan 'pencapaian konsep' menunjukkan wujudnya kesan positif penggunaan penggunaan penentuan utama ke arah mencapai konsep

Kata kunci Kunci penentuan, Pencapaian konsep, Keupayaan

klasifikasi, Kursus Vertebrate Zoologi.

\section{INTRODUCTION}

Determination key has been use in zoology vertebrate course to reflect the optimal structure of the concept because the Zoology Vertebrate course consist of important materials structure with the attributes of the concept and its examples. In zoology vertebrate course we have to learn many kind of concepts with their examples. In this course we have to learn such concepts according to the systematic of vertebrate animals. Determination key is very helpful for the students to learn about the classification according to the taxonomy. The taxonomy consist of the Kingdom- Phylum- ClassisOrder- Family - Genus- Species. According to the systematic of the taxonomy above it was known that species is the lowest unit of classification. It means that the animal that has the same characteristics were grouped in the smallest unit of the classification system. Based on the classification system, it has been known that species is the smallest unit of the classification system. It means that all animals of the same characteristics are belongs to the same species.

The combination of conceptual knowledge and the deeper knowledge should be useful to help students to classify and interpret what they have known in the real life. So, it is very important for teachers to teach the students to interpret what they have found on the real life and teach them for a deep comprehension about conceptual. Determination key is a kind of tool that consists of such steps to identify animals into such taxonomy from phylum up to species. This step is very helpful for students to learn about the classification of vertebrate animals, and not only to recall the structures, morphology, anatomy, reproduction system, habitat, geography and the name of species. These are the reasons for us why it is very important to develop the determination key of vertebrate animals.

Based on the reasons above, developing the determination key become important in this course because it can be such a tool to know the students' concept comprehension to use it make conclusion about the animals by using determination key. It was proof in this research that the use of determination key is very important, and can be used as a tool of how better they were classifying vertebrate animals in this course. When the students are better on using the determination key they also be better on the skill of classifying vertebrate animals, and the better on using determination key of vertebrate zoology become also better on their concept comprehension. So there is a correlation between Classification ability and concept attainment is quite 
high $(0,736)$, and the coefficient of determination is $54.16 \%$. It means that $54.16 \%$ of determination key was influenced by students' classification ability. So determination key is very useful for practical based instruction in laboratory activities as well in outdoor activities such as in Safari Garden or Zoological garden

\section{RESEARCH METHODS}

Researcher used mixed methods in this study that consist of qualitative and quantitative approach. Qualitative analyses on descriptive methods and quantitative analyses we used through correlation method. The research of mix strategy was using concurrent triangulation model where the collection of qualitative and quantitative data were taken in the same time. Then, the data were compared each other to identify the convergence and the combinations of the data as well (Cresswell, 2010).

The qualitative method was applied on the ability of students on using determination key, while the quantitative method was applied on the analyses of concept comprehension. The use of both methods was also applied to identify the use of determination key and classification ability to make the conclusion. We hope through this design we could get the picture of the students' classification ability as a whole Rubric Assessment is used for the practical report that consist of some activity indicators on using determination key in practical reports. These indicators were based on specific indicators Science process skill (Rustaman et al., 2003), that consist of (1) to identify the difference of some objects (2) To identify the differences of the objects, (3) to compare some objects (4) to identify the similarity of the object. All of the assessment on the practical activities were also based on specific classification ability that are known as Science Process Skill (Rustaman, dkk., 2003).

Population in this research is the characteristics of Classification ability and the Concept comprehension of the students of third semester in of 2013. The population in this research is the characteristics of Classification ability and Concept Comprehension of $4^{\text {th }}$ semester student in Biology Department that take the Zoology Vertebrate Course.

\section{RESULT AND DISCUSSION}

According to the indicator of classification ability, (Rustaman dkk., 2003), the main indicator of the grouping ability was 35\% (Fig.1). The result was the highest proportion for classification ability of vertebrate animals, by using determination key. 


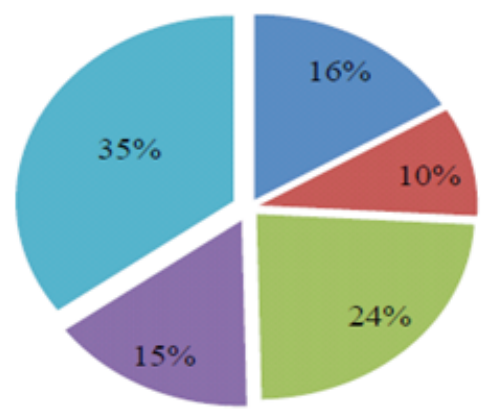

- comparing the objects

- contrasting the object

- - to find the differences among objects

- : to find the similarities among objects

=. to find the based of grouping objects

Figure 1 Proportion of the indicator of classification

The proportion of classification ability of vertebrate animals by using determination key was increase in all indicators of students' classification ability. The highest is for the indicators of 'finding the similarities among objects groups, that is 26.7 point. The lowest is for the indicators 'finding the differences among object group, that is only 0,3 point (Fig. 2). By the way by using test of differences, we found that there is no significant differences between the first data and the second data; $p=0.075$ $(>0.05)$.

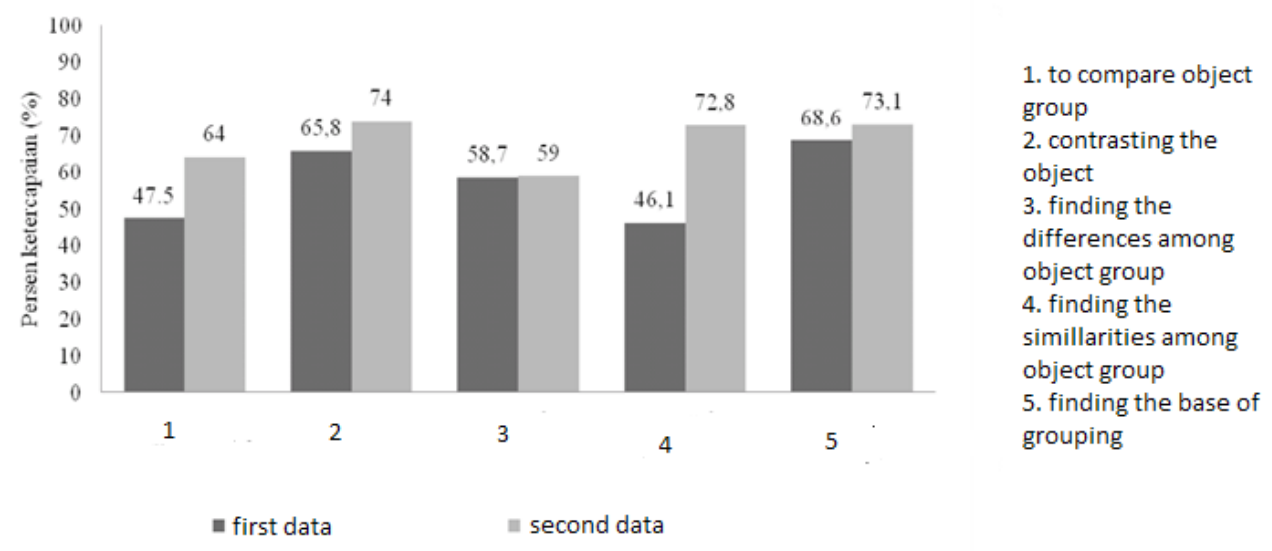

Figure2 Comparison of the proportion of such indicators of classification ability based on the time of data taken

The increase of students' ability in classification of vertebrate animals showed the determination key is very useful in vertebrate zoology course. According to Randler (2008), the use of determination key is very important to see the learning object completely the determination key give us the possibilities on determining the objects completely and to look more details of the objects and to clarify it scientifically. According to Watson and Miller (2009). 
The use of determination key in the learning process could develop the students' creativity and students reasoning. It also motivates the students to learn more easy, by comprehending, comparing, and analyzing the subject matter.

The profile analyses of concept comprehension were based on the indicators of each cognitive process according to Bloom's taxonomy. Students comprehension in this research based on cognitive process is below in (table 1).

Table 1 Indicators of students' concept comprehension

\begin{tabular}{cclc}
\hline No & $\begin{array}{c}\text { Cognitive } \\
\text { process }\end{array}$ & \multicolumn{1}{c}{ indicators } & $\begin{array}{c}\text { Mean } \\
\text { proportion (\%) }\end{array}$ \\
\hline 1 & Recall (C1) & $\begin{array}{l}\text { To understand the basic concept of } \\
\text { vertebrate animals. } \\
\text { To understand the classification of vertebrate } \\
\text { animals. }\end{array}$ & 71.7 \\
2 & $\begin{array}{l}\text { Comprehension } \\
\text { (C2) }\end{array}$ & $\begin{array}{l}\text { To understand the facts and the principal of } \\
\text { vertebrate characteristics } \\
\text { To understand the facts and the principal } \\
\text { based on the vertebrate classification. }\end{array}$ & 64.1 \\
& & $\begin{array}{l}\text { To apply the concept and the principal } \\
\text { of vertebrate classification in such a new } \\
\text { situation. }\end{array}$ & 74.2 \\
\hline
\end{tabular}

The result of this research show increasing points in every indicator of cognitive process. The highest was 35.6 points for Concept application (C3), and the lowest was for Concept Comprehension (C2) for only 4,1 points (Fig 3 ). Although both data was only 4.1 points (Fig 3). Mean differences test that were done to both data (the first test and the second test) showed no significant differences with $\mathrm{p}=0.241(\mathrm{p}>0.05)$.

The next result showed the highest score is concept application (C3) with 35.4 points and the lowest was only 4.1 points for concept comprehension (Fig 3 ), but there is no significant difference between the first test and the second test; $p=0.241$ ( $p>0.05$. The concept comprehension was very important in learning biology. The determination key in vertebrate zoology give important experience because the students should be able to do observation, identification and classification among vertebrate animals and grouping the animals from kingdom, phylum, classes, order, family, genus, and species. So, the use of determination key give positive impact on students' concept comprehension. The research result of Rustaman et.al (2003:87) showed the more activities in the learning process in the classroom, the more positive impact towards students' concept comprehension. 


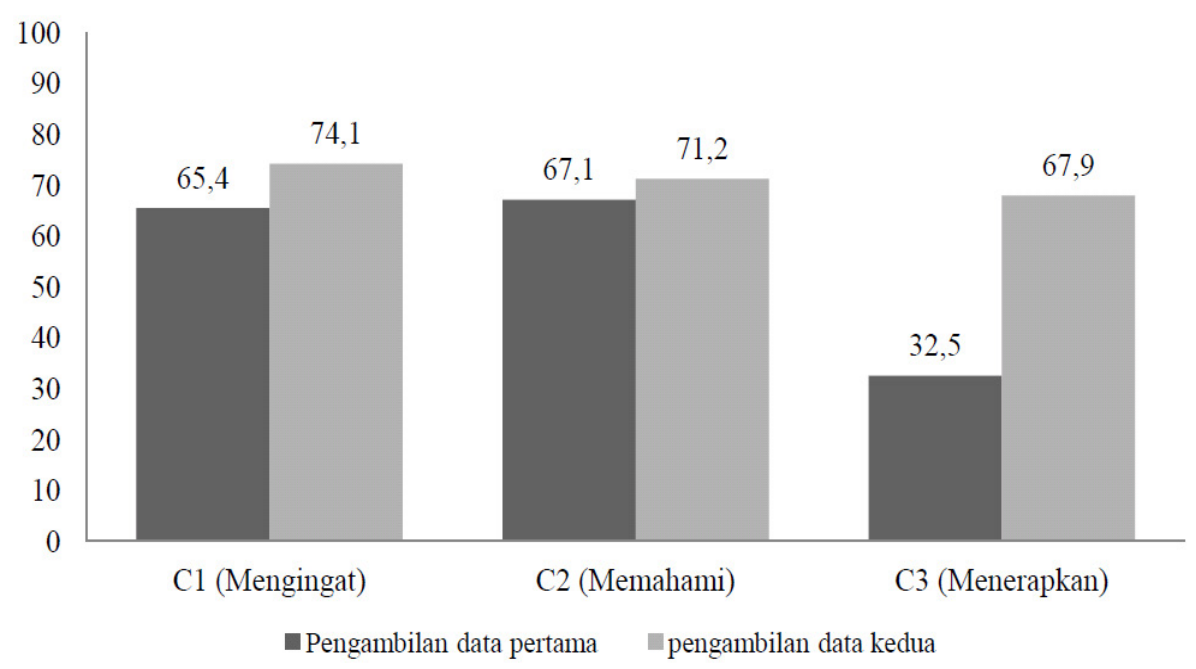

Figure 3 The Comparison of Data Proportion of such indicators On concept comprehension (first and second data)

Based on the analysis result the data showed strong relation between the classification abilities and the Concept comprehension. This assumption also give important implication towards the students that is: "the better on classification ability gave impact to the better on concept comprehension". Statistic testing showed correlation coefficient $(r)=0.736$ and determination coefficient $\left(R=r^{2}\right)$ $=54.16 \%$. It means that classification ability of the subjects can give $54.16 \%$ on concepts comprehension. It means that there is strong correlation between classification ability and concepts' comprehension by using the determination key.

There also significant value $\mathrm{p}=0.02(\mathrm{p} 0.05)$ that reject the null hypotheses $\left(\mathrm{H}_{0}\right.$ is rejected $)$. Based on these results it can be said that the use of determination key give positive impact toward students' abilities. Besides the quantitative data, this research also based the data analyses on descriptive analyses, that is the students' perception in using the key determination in learning vertebrate zoology (Fig. 4) 


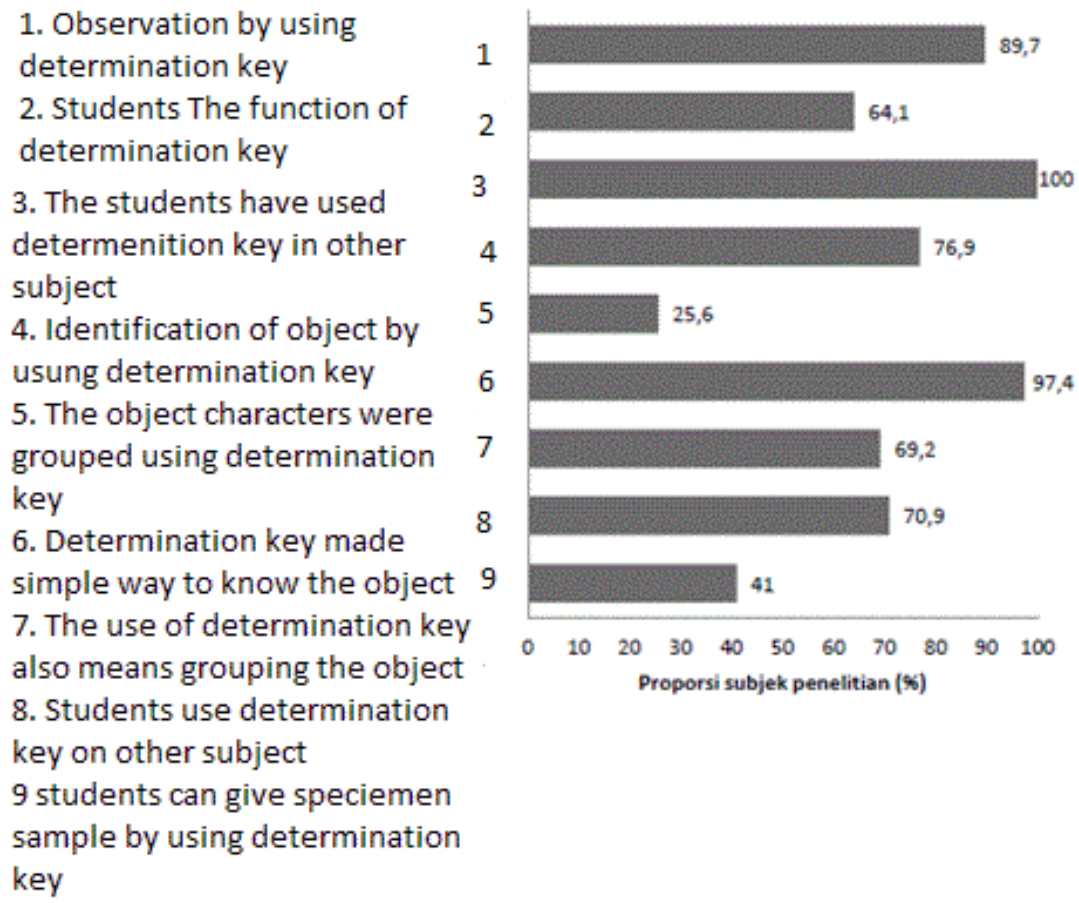

Figure 4 Students' Perception in Using Determination Key

Based on the questionnaires: it was known that $89.7 \%$ of the students have known the use of determination on learning other subjects, although only $64.1 \%$ that knew it better. About $97.4 \%$ of the subjects said that the use of determination key give better understanding to classify the objects. But, 25,6 \% said that the determination key can also be used to grouping the objects as well. This facts is relevant with the data that not all of the students $(70.9 \%)$ have use the determination key, but only $41 \%$ can make simple determination key. Although they can use the determination key, but some of the students still make some mistakes especially to maximize in using key determination to improve the learning process on practical activity and the learning abilities as well.

The important learning outcomes of the students are to improve their learning ability when they classify any vertebrate animals they found out of the classroom. We hope that this key determination could give them easy way to learn effectively in the future. It was hope that successfully teacher not only because of their charismatic appearance but because they have cognitive abilities and social task to do their best on improving students' ability and another social task of their profession. This task is also have similarity to the constructivism approach in the learning process. This process is important for students to know about the natural phenomenon, and also to meet the constructivist idea on learning process. 


\section{SUMMARY}

Based on the data it can be concluded:

1. The use of determination key on zoology vertebrate course could improve the classification abilities and the concept comprehension.

2. The students' ability on comprehending the facts and the principles of classification is better than before. The proportion of concept comprehension was $74,2 \%$.

3. There is strong improvement in all indicators in concepts' comprehension (C3) that reach 35.4 points higher than before using determination key.

4. The strong relation between classification abilities and concept comprehension show that there is positive effect in using determination key.

\section{REFERENCES}

Anderson, L.W dan Krathwohl, D.R. (2010). Kerangka Landasan untuk Pembelajaran, Pengajaran dan Asesmen. Revisi Taksonomi Pendidikan Bloom. Yogyakarta: Pustaka Pelajar.

Creswell, J.W. (2002). Educational Research: Planning, Conducting, and Evaluting Quantitative and Qualitative Research. Upper Saddle River, New Jersey: Merril.

Randler C. (2008). Teaching Species Identification a Prerequisite for Learning Biodiversity and Understanding Ecology. Eurasia Journal of Mathematics Science \& Technology Education, 4 (3) 223-231.

Rustaman, N.Y., Dirdjosoemarto, S., Yudianto, S.A., Ahmad Y., Subekti, R., Rochintaniawati, D., Nurjhani M. (2003). Strategi Belajar Mengajar Biologi Common Text Book. Jurusan Pendidikan Biologi FPMIPA UPI

Watson S, Miller T. (2009). Classification and the dichotomus key tools for teaching identification (report). Article: The Science Teacher:5054 (diakses tanggal 17 Januari 2012) 